\title{
The Hindrance of Doubt: Causes of Language Anxiety
}

\author{
Renxia Zhang ${ }^{1} \&$ Jian Zhong ${ }^{1}$ \\ ${ }^{1}$ Department of College English, Guangdong Polytechnic Normal University, Guangzhou, China \\ Correspondence: Renxia Zhang, Department of College English, Guangdong Polytechnic Normal University, No. \\ 293, Zhongshan Avenue, Guangzhou 510665, Guangdong, China. E-mail: renxia791122@163.com
}

Received: March 5, 2012 Accepted: March 21, $2012 \quad$ Published: June 1, 2012

doi:10.5539/ijel.v2n3p27 URL: http://dx.doi.org/10.5539/ijel.v2n3p27

\begin{abstract}
Language anxiety is independent of other general types of anxiety manifestations. This paper examines the possible causes of language anxiety in that a wider range of insights can be gained for effective foreign language teaching. A close review of the literature enables us to categorize language anxiety as learner-induced, classroom-related, skill-specific, and some culture-imposed, depending on different contexts. The potential sources provide us with an insightful view in the understanding of the difficulties students may have encountered in their process of language learning.
\end{abstract}

Keywords: foreign language teaching, anxiety, causes

\section{Introduction}

Over the last few decades, researchers have focused attention to the role of affective variables in addition to cognitive factors in the process of second language learning. As Stern (1983) noted, "[w]hatever specific findings may emerge as generalizations it may be stated that the affective component contributes at least as much as and often more to language learning than the cognitive skills represented by aptitude assessment” (p.386). Affective variables are usually defined as "the emotional side of human behavior in the second language process" (Brown, 1987, p.99). Along with the cognitive side, affective and social sides are interrelated in the learning process (Scovel, 1991). Among all of the affective variables, anxiety is one of the most researched and its interpretation is often inconclusive. However, it is one of the reliable predictors of successful second language learning (Gardner, 1985). Therefore, to have a close examination of anxiety in terms of its sources on second language learning is the aim of this paper.

\section{What Is Language Anxiety?}

For psychologists, anxiety can be described by distinguishing between trait anxiety and state anxiety. Trait anxiety refers to a person's inborn tendency to be anxious (Scovel, 1991). State anxiety is considered to be a temporary apprehension induced by a particular situation (Spielberger, 1983, cited in Ellis, 1994). State anxiety can be applied to specific situations, such as examinations or public speaking in language classrooms. While there exist different concepts of anxiety, I am choosing language anxiety as the point for discussion in this paper.

Language anxiety is defined as the fear or apprehension occurring when learners have to perform tasks in a target language in which they are not proficient (Gardner \& MacIntyre, 1993). Early studies view language anxiety as a manifestation of other types of anxiety, such as trait anxiety, test anxiety or public-speaking anxiety (Daly, 1991; Scovel, 1991). More recently, researchers have generally agreed that language anxiety is a unique and distinct anxiety independent on other general types of anxiety (Horwitz, Horwitz \& Cope, 1986). Although language anxiety sometimes could be considered as facilitative if mild, the overall negative effect on second language learning is worth noticing.

\section{Possible Causes for Language Anxiety}

In view of the general negative impact of anxiety on second language learning, it is important to examine the possible causes of language anxiety so that a wider range of insights can be gained for effective teaching and learning. A close review of the literature on language anxiety enables us to categorize it as learner-induced, classroom-related, skill-specific, and some society-imposed depending on different contexts. 


\subsection{Learner-induced Anxiety}

Learner-induced anxiety may result from learners' erroneous beliefs, unrealistic high standards, poor language abilities, self-perceived incompetence, inclined competitive nature and dispositional fear of negative evaluation.

Learners' unrealistic or erroneous beliefs about language learning is mainly responsible for the cause of anxiety. For example, Horwitz (1988) studied the varying beliefs of beginning university foreign language students about language learning. Results indicated that students showed great concern over the accuracy of their utterance. Hence, students tend to view that the target language should not be attempted unless correction is intervened and that they should not guess the meaning of an unknown word (Horwitz, Horwitz, \& Cope, 1986). Furthermore, some learners underestimate the difficulty of the language learning task and believe that two years or less is sufficient for them to become proficient in another language (Horwitz, 1988). A belief such as this may lead to their frustration and anxiety once their expectations about language learning clash the outcomes in reality. Moreover, some students even think they lack the aptitude or gift to learn a new language (Price, 1991).

In addition to unrealistic beliefs, learners may feel nervous if they fail to achieve the standards of their expectation. For instance, Kitano (2001) states that students are often exposed to the expert language of native speakers from tapes, videos, and instructors. They therefore set their standards as high as the level of native speakers, which leads to anxiety because of their inability to attain the high standards. Similarly, Gregersen and Horwitz (2002) conducted an interview study to investigate the relationship between foreign language anxiety and perfectionism. The findings showed that the anxious and nonanxious subjects differed in their personal performance standards. The anxious participants tended to displease with their performance shown in a videotaped oral interview even their abilities were obviously higher than others, whereas the nonanxious counterparts realized their own weakness and set realistic personal standards and seemed satisfied with their own performance in English.

Nevertheless, sometimes for some students, even a very low standard can be intimidating. It is not the issue of the standard but the poor language ability either in the native language or in the second language. Sparks and Ganschow (1991) assert that those who have difficulties with native language systems are liable to experience the similar problems when they attempt to learn a foreign language and thus make them anxious. Also, it is quite conceivable that most teachers report that low English proficiency is responsible for student reticence (Tusi, 1996). Similarly, Gardener, Smythe, \& Brunet (1977, cited in Kitano, 2001) examined English-speaking students learning French at three different competency levels (beginning, intermediate, and advanced) in an intensive summer school context. Research findings also show that the increase of proficiency sometimes results in lowering anxiety.

On the other hand, it is not always the fact that anxious people caused by poor language ability actually have deficient language proficiency or inferior language capacity than their more self-assured counterparts (Horwitz et al., 1986; Daly, 1991). Often times, it is the language learners that tend to underrate their competency in target language productions. Researchers (Horwitz, 2001; Horwitz et al., 1986) have contended that foreign language anxiety mainly stems from students' low self-evaluation of competence or individual's self-concept being challenged or threatened in communication. Price's (1991) qualitative interview echoes the claim that anxious learners tend to believe that their language abilities were less proficient than those of their classmates. Similar results were also provided by Gregersen (2003) who conducted an interview study to investigate how anxious and nonanxious English-learning Spanish students react to their own errors. The findings show that the apparent difference between anxious and nonanxious participants is that anxious learners have a "self-derogatory bias" toward their own competence (p. 29).

For some students, the tendency of forming low self-perception of competence is caused when language learners compare themselves to others or are negatively evaluated by their peers or teachers. Thus, many researchers contend that competitiveness (Bailey, 1983; Young, 1991) and fear of negative evaluation (Horwitz et al., 1986; Kitano, 2001; Gregersen, 2002; Young, 1991) were two of the primary causes of anxiety. Some anxious language learners tend to overly concern about the competence of others and compare their own performance in a self-underrated manner with those of their peers. In Bailey's (1983) diary analysis of competitiveness and anxiety in second language learning, subjects who like to compare themselves with other students are likely to feel stressful. On the other hand, Kitano (2001) considers fear of negative evaluation as a personality of anxious learners. The study found that the dispositional fear of negative evaluation was a source of anxiety in the college Japanese foreign language classroom, a finding yielding consistent results for the French and Spanish classroom in Horwitz’s (1986) study. 
In short, such learners' erroneous beliefs, unrealistic high standards, poor language abilities, self-perceived incompetence, inclined competitive nature and dispositional fear of negative evaluation are conducive for the development of language anxiety.

\subsection{Classroom-related Anxiety}

Albeit many potential sources of language anxiety are attributed to learners themselves, no one would deny that variables in the classroom are also the possible causes of language anxiety. Classroom-induced anxiety is mainly related to such variables as instructors, peers, or classroom practices.

Four instructor factors may be related to language anxiety -- instructor beliefs about language teaching, the manner of error correction, the level of perceived support, and the teaching style. Instructor beliefs about language teaching have been identified as a source of anxiety (Young, 1991). Language anxiety in the learner is probably caused when instructors consider their role as a constant error-corrector and "drill sergeant" rather than a "facilitator", when they do not promote group work for fear of losing control of the class, and when they believe teachers should be responsible for most of the talking and teaching (Young, 1991, p. 428). However, the more the teacher talk, the less the student participation, resulting in more silence that will force the teacher to talk more and gradually show more impatience (Tsui, 1996). Students thus will feel apprehensive under such a tense condition.

In addition, the stringent manner of error correction on the part of the instructor will likely lead to what Young called "inducing anxiety" (1991). Some students are afraid of their errors being corrected. Nevertheless, some students reported expecting to have their errors corrected and would feel uneasy if the instructor let errors go unnoticed or uncorrected (Young, 1990; Koch \& Terrell, 1991). Thus, it is the instructor's manner of error correction that matters, not the error correction itself.

Moreover, the degree of perceived teacher support is highly related to learners' feelings of anxiety (Trickett \& Moos, 1995, cited in Horwitz, 2001). As cited in Aida’s (1994, p. 164) paper, Appleby (1990) reported that teachers who are "unempathetic" with learner needs and language deficiencies make them greatly annoyed.

Furthermore, anxiety is also related to instructors' teaching styles according to the s five-year ongoing study by Oxford (1999). Some frequently appearing style conflicts as sources of anxiety in language classroom were reported. For example, students who are displeased with ambiguity (e.g., no details for projects or no syllabus) will feel anxious by their instructor who favors a loosely-patterned class climate. Also, it is possible that students whose learning preference is not particular-oriented will feel stressful when their teachers insist on precise details. Further, students become tense when their strong sensory preferences (e.g., learning by seeing instead of simply listening) are neglected by their instructor. Accordingly, foreign language anxiety can be aggravated when there is "a clash between the style of a particular language learner and the style of a given language teacher” (Oxford, 1999, p. 217).

In parallel with the teacher-induced anxiety, anxiety can also be induced by peers. For example, Allwright and Bailey (1991) indicated that some very competent students feel great peer pressure because their linguistic superiority over others might stir up the resentment and jealousy from their peers. Consequently, they may knowingly make mistakes, yet by which teachers probably find fault with them, or simply withdraw from the classroom interaction so as to find a way out of their dilemma. Thus, the less competent learners are not the only possible candidates susceptible to anxiety; even the high-proficient students get the blues.

A further point to be noted is that learners consistently report that they fear the possibility of looking "foolish" or "dumb" subsequent to the evaluation of their peers (Young, 1991; Gregersen, 2003). It was echoed by the findings shown in Gregersen's (2003) study that all of the anxious Spanish-speaking English learners reported their fear of being laughed at by peers or conversational partners when speaking the target language whereas not even a single non-anxious learner did.

Last, but not least, as Hellison (1996) reported in a case study, her learner also expressed discomfort by saying that "I didn't like this school because people care about grade so much.” (p. 267) Thus, the resentment, derision and competitiveness of their peers toward learners' performance may be a catalyst provoking language anxiety.

Another possibility of anxiety is generated by classroom practices, such as the types and nature of the task, the target language use as well as the classroom climate. The language learners in Price's study (1991) felt that having to speak the target language in front of the class is the greatest source of anxiety. Similarly, Koch and Terrell found that over $50 \%$ of their subjects reported oral presentations in front of the class and oral skits are two most anxiety-evoking activities in their Natural Approach classes. If oral activities are indispensable in class, Young (1990) found that her American second language learners would prefer to take part in the activities in 
small groups instead of in front of the whole class. Additionally, students are afraid of being "spotlighted" to answer questions in the target language (Young, 1990, p. 546). By contrast, the level of anxiety in writing compositions at home and reading silently for Young's (1990) learners is lower than that in speaking the target language before others.

Therefore, it seems logical to hypothesize that the more difficult the target language is, the more anxious the learners may be. The hypothesis is supported by Saito and Samimy (1996). They found that the perceived level of the difficulty of the Japanese language, which is particularly anxiety-ridding for beginning English-speaking students, is one of the reasons to cause high attrition rates among American university students studying Japanese. Similarly, the difficulty of instruction by using the target language exclusively in class generates apprehension for some advanced-level students (Kitano, 2001). Nevertheless, in his latest article, Levine (2003) examined the relationship between target language (TL) and first language (L1) use in university-level foreign language classes. Surprisingly, analysis of the data revealed a negative relationship between TL use and TL-use anxiety. In other words, greater TL use may not transfer to higher anxiety among students because many learners may feel relaxed with more TL use when that is what they are accustomed to. The author hence cautions us that the complete obviation of L1 use may be a source of TL-use anxiety. That is to say, L1 could sometimes be used for the purpose of alleviating anxiety and maximizing efficiency in classroom practices.

On top of the issue of TL use, many learners expressed their insecurity when they were asked to compare their own writing work with their peers in class. By so doing, a feeling of classroom competitiveness may be heightened (Hilleson, 1996). According to Horwitz's (2001, p. 119) review of the literature of anxiety, she cited a study conducted by Palacios (1998) that investigated the relationship between class climate and students' levels of foreign language anxiety. The findings showed that "classroom levels of affiliation among the learners, lack of competition, and clear task orientation" contribute to lower levels of anxiety.

\subsection{Skill-specific Anxiety}

Research has consistently shown that speaking in the foreign language is the most anxiety-provoking experience for many students (Price 1991; Young 1990), even those who never experience stress in all other fields of language learning (Horwitz et al., 1986). Price's (1991) reports on interview with highly anxious former language students also indicated that his participants could not care less about their imperfect pronunciation. Specifically, several people felt ashamed of their Texas accents. Also, some learners felt uncomfortable in that their ability to make small talk or oral production was denied as a result of their poor vocabulary of the target language (Hilleson, 1996). Besides the poor vocabulary of the target language, the overwhelming number of rules required to speak language may make learners nervous one degree or another (MacIntyre, 1995). What is more, unprepared free speech is mentioned as contributing to heightened language anxiety (Horwitz et al., 1986).

Although speaking is the skill identified as the most anxiety-generating in the literature of language anxiety, Krashen at a personal interview (Young, 1992) emphasized that listening comprehension is also greatly anxiety-ridding "if it [the discourse] is incomprehensible" (p.168). According to Vogely (1998), the most noticeable sources of listening comprehension anxiety reported in her questionnaire study of university Spanish-learning students were (1) the nature of the speech (e.g. fast speech pace, various accents, poor pronunciation, and too soft voice); (2) inappropriate strategies (e.g. word-for-word input decipherment); and (3) the level of difficulty (e.g. unknown words, difficult sentence structure, or unfamiliar topics). Language learners cannot banish anxiety to interact verbally without an understanding what they hear. Therefore, the task of listening comprehension is one of the contributing sources of language anxiety.

Just as seen in listening and speaking, reading in the second language, too, may be associated with language anxiety. Reading anxiety has been examined by Saito et al. (1999). These researchers found that readers' language anxiety is aroused because of the unfamiliar culturally-related content or its high level of difficulty. In addition, readers are afflicted with recurrent frustrations when they are incapable of comprehending every word and idea in a text (Lee, 1999). Moreover, Lee (1999) pointed out other misconceptions that lead to anxiety. Students are usually asked to understand a short paragraph simply based on their correct answers to the accompanied comprehension questions. This may limit the students' familiarity with the text because they may know nothing beyond the answered questions. Furthermore, readers may feel frustrated and anxious as they proceed through the text without the adequate assistance by others.

Reading apart, anxiety may also occur if learners are requested to write in the target language. Leki (1999) enumerates the possible sources of writing anxiety. For example, students may be anxious about their writing because their linguistic capability in the target language is not competent enough to deal with the idea they intend to express. It is also possible that language teachers who claim to value students' ideas over their forms 
and yet grade a piece of writing mainly depending on the second language forms. Students thus feel confused and uneasy about what the instructor actually favors. Moreover, teachers may mislead students to an apprehensive situation by dealing with students' writing works as a test of structural knowledge instead of as a communicative adventure in which language learners associate linguistic forms with the ideas for topics.

The skill-specific anxiety is sometime correlated with test-taking. If a student studies diligently before a test and only finds that s/he fails owing to an unfamiliar test format that is never utilized in class, they may feel uncomfortable (Young, 1991). It is also possible that students may react uneasily because they are tested in a way which does not actually reflect how classroom practices are carried out (Young, 1991). Simply put, students taught with a communicative approach may be overwhelmed when they are really given a test mainly based on grammatical aspects. This may bring about tensions and frustration to students (Young, 1991).

\subsection{Society-imposed Anxiety}

Society-imposed anxiety here refers to language anxiety caused by the society that embraces identity formation, cultural connotation, and parental intervention. Anxieties related to identity formation center primarily on the process labeled "subtractive bilingualism", a term coined by Lambert (1974, cited in Ellis 1994) as where members of a minority group learn the dominant language as L2 [second language] and are more likely to experience some loss of ethnic identity and attrition of L1 [first language] skills. One anxious English-learning student respondent in Hilleson's (1996) introspective study talked about her discomfort at losing her linguistic identity. She found unexpectedly that she not only felt disadvantaged in English but also spoke Norwegian unnaturally, which resulted in her sense of losing self-identity. Simply put, those who see the acquisition of English as a threatening process as "subtractive bilingualism" are more likely to be stressful.

In addition to identity formation, cultural differences should be taken into account when addressing the issue of language anxiety (Horwritz, 2001). Some learners may bring their own cultural values or habits with them into the language classroom. Therefore, students' involuntarily answering questions in class sometimes could be attributed to the lack of confidence, but it could also be as a result of different socio-cultural values, such as the emphasis of keeping silent as a modest rule for Chinese students (Tusi, 1996). Additionally, in 2003, Allen (2003) conducted a study to investigate the linguistic and affective outcomes for college students after joining a summer study program in France. An analysis of data suggested that cultural differences were one of the key sources of their language anxiety. For example, they felt uncomfortable when they had to explain their dietary habits and vegetable necessity to their hosts.

On the other hand, parents' great expectation was found to be an important source of language anxiety (Liao, 1999). Based on the analysis of interview data collected from Taiwanese junior high school students, Liao (1999) reported that students felt anxious because their parents expected them to study English as well as other high achievers or believed that mastering English is the only route for their children to communicate with others.

In brief, the potential sources reported above provide us with an insightful view to understand the difficulties and failures students may have encountered in their process of language learning. Once these causes of language anxiety can be thoroughly identified, we may look into the direction for further identify the effects of anxiety on second language development.

\section{Conclusion}

Some anxiety is caused by so many factors, and has repercussions on the learners' overall language development, a cross-session survey or a short-term case study might not be sufficient methodological approaches for us to really understand the nature of anxiety. The future direction of research in this area should be more comparative, and more contextualized as learning a second or foreign language is not free from anxiety, but each individual learner copes with anxiety differently, and yet their coping strategies will likely help us trace the causes in context. A sociolinguistic approach to the study of anxiety coupled with a number of other pertinent affective variables such as motivation, attitudes, risk-taking, and self-esteem will likely reshape our understanding of how a second or foreign language is learned, and/or not learned.

\section{References}

Aida, Y. (1994). Examination of Horwitz, Horwitz, and Cope's construct of foreign language anxiety: The case of students of Japanese. The Modern Language Journal, 78(2), 155-168. http://dx.doi.org/10.1111/j.1540-4781.1994.tb02026.x

Allen, H. W. (2003). A mixed-methodology investigation of the linguistic and affective outcomes of summer study abroad. Foreign Language Annals, 360-385. http://dx.doi.org/10.1111/j.1944-9720.2003.tb02120.x 
Allwright, D., \& Bailey, K. M. (1991). Focus on the language classroom: An introduction to classroom research for language teachers. Cambridge: Cambridge University Press.

Bailey, K. M. (1983). Competitiveness and anxiety in adult second language learning: Looking at and through the diary studies. In H. W. Seliger \& M. H. Long (Eds.), Classroom oriented research in second language acquisition (pp. 67-102). Rowley, MA: Newbury House.

Brown, H. D. (1987). Principles of language learning and teaching. Englewood Cliffs, NJ: Prentice-Hall.

Daly, J. (1991). Understanding communication apprehension: An introduction for language educators. In E. K. Horwitz \& D. J. Young (Eds.), Language anxiety: From theory and research to classroom implications (pp. 3-13). Englewood Cliffs, NJ: Prentice Hall.

Ellis, R. (1994). The study of second language acquisition. Oxford: Oxford University Press.

Gardner, R. C. (1985). Social psychology and second language learning: The role of attitudes and motivation. London: Edward Arnold.

Gardner, R. C., \& MacIntyre, P. D. (1993). On the measurement of affective variables in second language learning. Language Learning, 43, 157-194. http://dx.doi.org/10.1111/j.1467-1770.1992.tb00714.x

Gregersen, T. S. (2003). To err is human: A reminder to teachers of language-anxious students. Foreign Language Annals, 36(1), 25-32. http://dx.doi.org/10.1111/j.1944-9720.2003.tb01929.x

Gregersen, T., \& Horwitz, E. K. (2002). Language learning and perfectionism: Anxious and non-anxious language learners' reactions to their own oral performance. The Modern Language Journal, 86(4), 562-570. http://dx.doi.org/10.1111/1540-4781.00161

Hilleson, M. (1996). Reticence and anxiety in second language learning. In K. M. Bailey \& D. Nunan (Eds.), Voice from the language classroom (pp. 248-277). New York: Cambridge University Press.

Horwitz, E. K. (1986). Preliminary evidence for the reliability and validity of a foreign language anxiety scale. TESOL Quarterly, 20, 559-564. http://dx.doi.org/10.2307/3586302

Horwitz, E. K. (1988). The beliefs about language learning of beginning university foreign language students. The Modern Language Journal, 72(3), 283-294. http://dx.doi.org/10.1111/j.1540-4781.1988.tb04190.x

Horwitz, E. K. (2001). Language anxiety and achievement. ARAL, 21, 112-126.

Horwitz, E. K., Horwitz, M. B., \& Cope, J. (1986). Foreign language classroom anxiety. The Modern Language Journal, 70(2), 125-132. http://dx.doi.org/10.1111/j.1540-4781.1986.tb05256.x

Kitano, K. (2001). Anxiety in the college Japanese language classroom. The Modern Language Journal, 85(4), 549-566. http://dx.doi.org/10.1111/0026-7902.00125

Koch, A. S., \& Terrell, T. D. (1991). Affective reactions of foreign language students to Natural Approach activities and teaching techniques. In E. K. Horwitz, \& D. J. Young (Eds.), Language anxiety: From theory and research to classroom implications (pp. 109-126). Englewood Cliffs, NJ: Prentice Hall.

Krashen, S. (1981). Second language acquisition and second language learning. Oxford: Pergamon.

Lee, J. F. (1999). Clashes in L2 reading: Research versus practice and readers' misconceptions. In D. J. Young (Ed.), Affect in foreign language learning: A practical guide to creating a low-anxiety classroom atmosphere (pp. 49-63). Boston: McGraw Hill.

Leki, I. (1999). Techniques for reducing second language writing anxieity. In D. J. Young (Ed.), Affect in foreign language learning: A practical guide to creating a low-anxiety classroom atmosphere (pp. 64-88). Boston: McGraw Hill.

Levine, G. S. (2003). Student and instructor beliefs and attitudes about target language use, first language use, and anxiety: Report of a questionnaire study. The Modern Language Journal, 87(3), 343-364. http://dx.doi.org/10.1111/1540-4781.00194

Liao, Y. (1999). The effects of anxiety on Taiwanese EFL learners. The Proceedings of the Eighth International Symposium on English Teaching, 11-13, 453-463.

MacIntyre, P. D. (1995). How does anxiety affect second language learning? A reply to Sparks and Ganschow. The Modern Language Journal, 79(1), 90-99. http://dx.doi.org/10.1111/j.1540-4781.1995.tb05418.x 
MacIntyre, P. D. (1999). Language anxiety: A review of the research for language teachers. In D. J. Young (Ed.), Affect in foreign language and second language learning: A practical guide to creating a low-anxiety classroom atmosphere (pp. 24-45). Boston: McGraw Hill.

Oxford, R. L. (1999). "Style wars" as a source of anxiety in language classrooms. In D. J. Young (Ed.), Affect in foreign language and second language learning: A practical guide to creating a low-anxiety classroom atmosphere (pp. 216-237). Boston: McGraw Hill.

Price, M. L. (1991). The subjective experience of foreign language anxiety: Interviews with highly anxious students. In E. K. Horwitz \& D. J. Young (Eds.), Language anxiety: From theory and research to classroom implications (pp. 101-108). Englewood Cliffs, NJ: Prentice Hall.

Saito, Y., Horwitz, E. K., \& Garza, T. J. (1999). Foreign language reading anxiety. The Modern Language Journal, 83(2), 202-218. http://dx.doi.org/10.1111/0026-7902.00016

Saito, Y., \& Samimy, K. K. (1996). Foreign language anxiety and language performance: A study of learner anxiety in beginning, intermediate, and advanced-level college students of Japanese. Foreign Language Annals, 29(2), 239-251. http://dx.doi.org/10.1111/j.1944-9720.1996.tb02330.x

Scovel, T. (1991). The effect of affect on foreign language learning: A review of the anxiety research. In E. K. Horwitz \& D. J. Young (Eds.), Language anxiety: From theory and research to classroom implications (pp. 15-23). Englewood Cliffs, NJ: Prentice Hall.

Sparks, R. L., \& Ganschow, L. (1991). Foreign language learning differences: Affective or native language aptitude differences? The Modern Language Journal, 75, 3-16. http://dx.doi.org/10.1111/j.1540-4781.1991.tb01076.x

Stern, H. H. (1983). Fundamental concepts of language teaching. Oxford: Oxford University Press.

Tsui, A. B. M. (1996). Reticence and anxiety in second language learning. In K. M. Bailey \& D. Nunan (Eds.), Voice from the language classroom (pp. 145-167). New York: Cambridge University Press.

Vogely, A. J. (1998). Listening comprehension anxiety: Students' reported sources and solutions. Foreign Language Annals, 31(1), 67-80. http://dx.doi.org/10.1111/j.1944-9720.1998.tb01333.x

Young, D. J. (1990). An investigation of students' perspectives on anxiety and speaking. Foreign Language Annals, 23(6), 539-553. http://dx.doi.org/10.1111/j.1944-9720.1990.tb00424.x

Young, D. J. (1991). Creating a low-anxiety classroom environment: What does language anxiety research

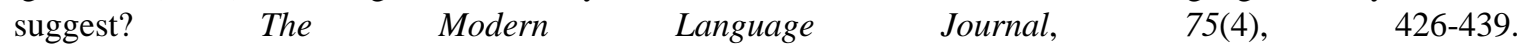
http://dx.doi.org/10.1111/j.1540-4781.1991.tb05378.x

Young, D. J. (1992). Language anxiety from the foreign language specialist's perspective: Interviews with Krashen, Omaggio Hadley, Terrell, and Rardin. Foreign Language Annals, 25(2), 157-172. http://dx.doi.org/10.1111/j.1944-9720.1992.tb00524.x 